\title{
Women contribution to the development of Buddhism in Latvia
}

\author{
Marika Laudere* \\ Daugavpils University, Daugavpils, Latvia
}

\begin{abstract}
Buddhism is one of the fastest growing and popular religions in the West which connects people of different ages and social classes. The significant role in the historical transmission of Buddhism to the West and in shaping a distinctively Western form of Buddhism has been played by Western women. Many of these women have gained attention for challenging traditional forms of Buddhism and adapting Buddhist teaching to the contemporary Western context. Others for trying to preserve traditional Buddhist teaching in new circumstances and establishing Asian Buddhist lineages in the West. As well all these women have engaged in a range of activities from teaching to translating, charity and social activism, to promoting Buddhism in the West.
\end{abstract}

Key words: Buddhism, women, Latvia, community, teaching.

\section{Introduction to Buddhism in Latvia}

During the $19^{\text {th }}$ and $20^{\text {th }}$ centuries, global flows of Buddhism have resulted in a vast diversity of Buddhist lineages and communities across the Western world, and Buddhism teaching became available to more people spreading around the world. For the first time in its history, Buddhism became one of the most widely practiced religions on all continents [1].

If initially the existence of Buddhism in the West was largely related to the activities of Buddhist migrants from Asia, starting from the beginning of the second-half of the $20^{\text {th }}$ century, Buddhism has aroused interest in Westerners themselves [2]. Such interest, firstly, was facilitated by the increased availability of translations of Buddhist literature and sacred texts, increasing the interest of spiritual seekers not only in meditation, but also in the nature of Buddhism teaching itself. Secondly, the active missionary work of Asian teachers and their visits to their founding groups in the West were of great importance. As a result, lectures and meditation seminars in these groups became available on a regular basis [3].

Under favourable conditions, the 1960s and 1970s experienced a rapid establishment of Buddhist groups, organizations, and institutions in America and many Western Europe countries. In its turn, since the end of 1980s a similar trend has been observed in Eastern Europe, driven not only by the spiritual search in the society through involvement in the new religious movements, but also by political developments in Eastern Europe, such as the fall of the Berlin Wall and the collapse of the USSR. As a result, new Buddhist groups began to form more rapidly in Poland, the Czech Republic, Hungary, and in the western part of the former USSR [4], including the Baltic region.

Buddhism in Latvia compared to the Western world does not have a long history. Though the first news on Buddhism reached Latvia already at the end of the $19^{\text {th }}$ century - the

\footnotetext{
* Corresponding author: marika.laudere@gmail.com
}

(C) The Authors, published by EDP Sciences. This is an Open Access article distributed under the terms of the Creative Commons Attribution License 4.0 (http://creativecommons.org/licenses/by/4.0/). 
beginning of the $20^{\text {th }}$ century, as well in 1920 s Buddhism was popularized by Karlis Tennisons (1883 - 1962) - the first Buddhist monk in the Baltic States, at that time there were no organized Buddhist groups in Latvia and Buddhism in general did not gain greater interest among a wider range of people.

The gradual formation of Buddhist groups in Latvia, unlike the Western countries, started only since the end of 1980s - the beginning of 1990s during the Soviet times in the years of "perestroika". Such a time difference is mainly explained by the political regime prevailing in Latvia, when religion as such was forced out of the public life during the Soviet occupation. Moreover, the prevailing ideological positions of the USSR provided that religion had no place in the communist society and attempts were made to replace all religious traditions with Soviet ones [5]. Despite the official policy of atheism proclaimed in the Soviet Union, the ban on religion did not lead to a complete loss of interest in the spiritual life in Latvia. As interest in one of the Christian denominations diminished, instead, starting since the last years of the USSR regime, another phenomenon was observed in Latvia. Respectively, public attention increased against the new religious movements and other esoteric teachings [6].

Younger generation longed for some overarching meaning of the life and read spiritual literature, which was available more freely and in larger amount than before. Thus, they began to congregate to explore and implement spiritual knowledge in practice. They often tried a variety of yoga, meditation techniques, etc., establishing unofficial religious groups as well [7]. After the restoration of Latvia's independence in 1991, some of these groups became officially registered organizations. The same is applied to groups practicing Buddhism, the number of which has increased over the last thirty years.

Currently more than ten Buddhist groups, which represent a variety of Buddhist teachings, are active in Latvia. As first should be mentioned Tibetan Buddhism, whose ideas reached Latvia at the end of 1980s and attracted imagination of religious seekers at that time. In general, Tibetan Buddhism in Latvia is represented by three of its four orders (traditions): Nyingma, Kagyu and Gelug. Tibetan Buddhism groups are the largest both in the number of communities and their members. The first of Tibetan Buddhism traditions in Latvia is Nyingma that is represented by the two Dzogchen ${ }^{1}$ teaching groups - "Padmalinga" and the centre of Buddhist teacher Patrul Rinpoche (1963). The most widespread order in the West, Kagyu, is represented in Latvia by two of its schools and it consists of several communities. They are Riga's and Daugavpils' Diamond Way Buddhism groups that belong to Karma Kagyu school and "Drikung Kagyu Dharmachakra centre", "Riga Drikung Ngaden Choling" and Tibetan Meditation and Healing centre "Sorig" which are associated with Drikung Kagyu school. The last Tibetan Buddhism order that came to Latvia at the beginning of the $21^{\text {st }}$ century is Gelug. At present, two meditation centres belong to this Buddhism tradition "Ganden" and "Den Nyi Ling" retreat centre.

The second Buddhism tradition that has set its roots in Latvia is Mahayana and it is represented by Zen Buddhism schools. Though ideas of Zen Buddhism already reached Latvia in the middle of 1990 s, only in the early $21^{\text {st }}$ century there were successful attempts to establish Zen Buddhism communities. Currently there are three Zen Buddhism schools in Latvia - groups that represent Kwan Um Zen Buddhism school, "One Drop Zendo Latvia" associated with Rinzai Zen Buddhism school and Soto Zen school centre in Riga.

The third tradition, Theravada, reached Latvia simultaneously with the teaching of other Buddhism traditions in the middle of 1990s. Theravada in Latvia is represented by the Association of Theravada Buddhism in Latvia and Vihara meditation group.

\footnotetext{
${ }^{1}$ Dzogchen - is a particular and ultimate teaching of the Nyingma tradition.
} 


\section{The research}

The data presented in the paper base on the fieldwork in several Buddhist communities in Latvia over a period of several years (the research took place between 2009 and 2016). The project utilized a qualitative approach and employed a combination of ethnographic methods, including participant observations and qualitative interviews. During the fieldwork, the main research aim was to explore the history and activities of Buddhist groups, but was not limited only to it.

During the research, over 60 semi-structured interviews were conducted, fully recorded and transcribed for the purpose of coding and analysis. The respondents were representatives of the main Buddhist communities in Latvia. Participant observation was undertaken within the several Buddhist communities in weekly meetings, retreats and public activities over the research period. Participation involved taking part in teaching, meditation and prayer sessions and some socializing.

\section{Women contribution to Buddhism in Latvia}

Each of the Buddhist traditions that have been introduced to Latvia has its own history. But since the beginning of the gradual introduction of Buddhism to Latvia, the important role in the establishment of many of Buddhist communities and in their further development was played by women. Women have played a variety of roles, emerging as leaders in some cases and playing supportive roles in others. In the further sections of this article the examples of how women have contributed to the development of Buddhism in Latvia will be presented.

\subsection{Women as a founder of Buddhist communities}

One of the first examples when women introduced Buddhism tradition to Latvia and founded a Buddhist community can be traced back to the early 1990s. In 1991 one of the current Buddhist practitioners in Latvia, Lana Jefremenko, took part in one of the spiritual seminars held in St. Petersburg at that time. In this seminar she first encountered the Tibetan Buddhism Kagyu tradition and its Drikung Kagyu school's one of the leading teachers Nubpa Konchok Tenzin Rinpoche [8]. At her invitation, in 1991 Nubpa Rinpoche arrived in the capital of Latvia, Riga. During his first visit to Latvia four students took the Buddhist refuge ${ }^{2}$ and this was the very beginning of the first Drikung Kagye school community in Latvia [9]. A year later, on September 24, the Drikung Kagyu Dharma Chakra Centre was registered, declaring Nubpa Rinpoche as its spiritual leader and Drikung Kyabgon Chetsang Rinponche, the 37th Patriarch of the Drikung Kagyu school, as the head of the centre [10].

Although the general society was poorly informed about the existence of Buddhism in Latvia, the community organized religious practices and sometimes held spiritual training sessions as well. For example, a month after the establishment of the centre, in October 1992, lectures were given at the Drikung Kagyu Dharma Chakra Centre by Alexander Berzin, a Buddhist and Buddhist practitioner [11]. Thanks to these and other activities, the number of members of the community slightly increased by the end of the 20th century. This allowed the centre to acquire the status of a religious organization. As a result, on January 27, 1999, the community was registered in accordance with the law in the Office of Religious Affairs of the Ministry of Justice [12], thus acquiring the rights and privileges provided for religious organizations.

2 Buddhist refuge - Buddhists take refuge in the Three Jewels: Buddha, Dharma (teaching) and Sangha (community). Taking refuge in the Three Jewels is considered the starting point on the Buddhist path. 
During disagreements between some of the members of this community [13], in the first years of the $21^{\text {st }}$ century, the drikung kagyu group split into three separately acting from each other communities: "Drikung Jamze Ling Dharmachakra centre", "Riga Drikung Ngaden Choling" and Tibetan Meditation and Healing centre "Sorig".

The last one, Tibetan Meditation and Healing centre "Sorig", was established in 2005 and still is led by Lana Jefremenko, a woman who brought Drikung Kagyu to Latvia. This community is known in Latvia by the fact that in 2008 it started the first stupa construction in Latvia - Peace Pagoda $40 \mathrm{~km}$ from Riga. The opening of the Peace Pagoda took place on June 28, 2014. Now it is open for both practitioners and other visitors. For practitioners Tibetan Meditation and Healing centre "Sorig" organizes different religious events such as meditations, practices and teachings. For other visitors there is a recreational park in the territory of the Latvian Peace Pagoda, which can be used by any Peace Pagoda visitor [14].

The next good example when a woman brought Buddhism teaching and established a Buddhism centre in Latvia is Daugavpils' Diamond Way Buddhism centre that represents Karma Kagyu School. In general, the history of Karma Kagyu School in Latvia started with the first visit of the founder of Diamond Way Buddhism organization in the West, Buddhist lama of Danish origin, Lama Ole Nidahl ${ }^{3}$ (1941). He came to Latvia in August 1997, and the visit resulted in the official registration of the community as a religious organization in the Office of Religious Affairs of the Ministry of Justice [15].

Although in the following years Ole Nidal's lectures in Riga became regular, similarly to other Buddhist groups that had formed in Latvia until then, the Diamond Way Buddhism centre did not gain a large support. One of the main reasons was not only society's low interest to Buddhism, but also the lack of permanent premises, which prevented the expansion of the community. Respectively, during the first-year religious practice took place in community members' homes, followed by the activity in the International Oriental Cultural Centre "Urusvati" and later in Reiki centre premises [16]. Only in 2002 situation in the community began to change, when the group purchased 175 square meters large premises in Riga for its own needs.

In its turn, Diamond Way Buddhism was brought to Daugavpils, the second largest city in Latvia, five years later, in 2002, by Daugavpils female painter Irina Petrusevich who encountered Buddhism and Diamond Way Buddhism organization while living in Copenhagen, Denmark. Returning to Daugavpils, she gathered around herself several artists and their acquaintances for meditation practice. Due to established contacts with followers of Diamond Way Buddhism in Riga, Lithuania and Denmark, as well as subsequent trips to various courses with Lama Ole Nidahl and other teachers of this Buddhist organization, Daugavpils Diamond Way Buddhism community gradually began regular Buddhist practices [17].

Not in all cases of the Buddhist communities' formation women were the main initiators to establish a Buddhist centre. Nevertheless, they had a significant role. One of the good examples is the establishment of Latvian Theravada Buddhist Society. In the summer of 1996, Ajahn Viradhammo (Vitauts Akers), a Buddhist teacher from Canada of Latvian origin, came to Latvia with the purpose to visit his parents' homeland and learn about his family roots [18]. While staying in Riga for some time, he established first contacts with a family couple in the summer of 1997. Later this family invited Ajahn Viradhammo to Latvia with the intention of conducting Buddhist teaching. The summer meditation camps or retreats led by Ajahn Viradhammo became regular in the next years and continued in Latvia until 2002. In the

\footnotetext{
${ }^{3}$ Lama Ole Nydahl (1941) is a Buddhist teacher in the Karma Kagyu school of Tibetan Buddhism, and founder of over 600 Buddhist centres worldwide for lay practitioners.
} 
end, these retreats laid the foundation for the establishment of a regular Theravada Buddhism practitioners' group in Latvia that was officially registered in 2005.

\subsection{Female leadership in Buddhist centres}

The visible role of women in Latvian Buddhist communities also manifests at Buddhist communities' institutional leadership positions. Regarding this one of the most interesting cases is "Ganden" Buddhist meditation centre that belongs to Gelug tradition associated with the Dalai Lama.

Establishment of this centre related to the second visit of the $14^{\text {th }}$ Dalai Lama (1935) to Latvia in 2001. One year earlier, in 2000, Uldis Balodis (1949), an Australian of Latvian origin, arrived in Riga to carry out preparatory works for this event. At that time, he was a head of the Buddhist centre in Melbourne, Australia, that belonged to an international organization the Foundation for the Preservation of Mahayana Tradition (FPMT). A head of this organization and a teacher of Uldis Balodis, Lama Thubten Yeshe ${ }^{4}$, selected him as the appropriate person to do this task [19].

Along with the preparation works, Uldis Balodis started to deliver lectures on Buddhism in the Latvian Academy of Culture, Riga, and to consult interested people privately. Step by step, a small group of practitioners was formed. These persons wanted to get to know Buddhism not only by receiving information during the lectures but also more deeply - by doing meditation practices. This motivated people to establish a regular Buddhist group that in 2003 was officially registered as "Ganden" meditation centre. The official registration as a religious organization took place in the Office of Religious Affairs of the Ministry of Justice in 2004 [20]. Thanks to integration into the FPMT, "Ganden" meditation centre was able to expand its program, offering a wider range of religious activities and hosting teachers of the Gelug tradition.

From the very beginning, one of the female Buddhism practitioners from this group occupied the post of director, and since the establishment of the community, three directors have already changed. In addition, the management of the FPMT organization, to which the list of appropriate candidates for this post is sent, makes the final decision on the appointment of the new director of the centre. In addition, the first female director of "Ganden" meditation centre after leaving this post established another Buddhism group of Gelug tradition in Latvia's countryside - Den Nyi Ling retreat centre.

In the case of several other Buddhist centres, women run the organization alongside men, following the organizational structure established in the international organization of the school, to which a particular Buddhist community belong. For example, Ganchi is the organizational council in one of the first Buddhist communities in Latvia "Padmalinga" (established already in 1991) that is one of the centres of the International Dzogchen Community founded by Chögyal Namkhai Norbu (1938-1918). Ganchi consists of three colour sectors - blue, red and yellow, headed by one of the members, and members elected in Ganchi coordinate the inner work and manage the relations with other centres of the Dzogchen Community worldwide. A board of five people regulate all activities of the Diamond Way Buddhist groups in Latvia. This board is legally responsible for organization, solves financial questions and makes important decisions. In both cases, these coordination boards are gender mixed and, in this way, gender balance is maintained in a decision-making process.

\footnotetext{
${ }^{4}$ Lama Thubten Yeshhe and Lama Thubten Zopa Rinpoche who were among the first Buddhist lamas in Nepal who taught Gelug tradition to Westerners. In 1974, they visited Europe for the first time. After this trip, an organization the Preservation of Mahayana Tradition was set up in 1975 to coordinate the activities of Gelug groups and centres.
} 


\subsection{Other forms of women engagement in Buddhism}

Undoubtedly, women contribute to the development of Buddhism in Latvia in other ways as well. Mostly it is participation in the life of a community, to which they belong. Primarily, it is participation in religious practice.

Despite that the first Buddhist communities were set up in 1990s their activity was limited by performance of simple religious practice that mostly took place in the rented premises or in a property belonging to the members of that community. However, in the new millennium, Buddhist communities gradually solved the problem related to the permanent location places and that, on its turn, gave an opportunity to broaden both, variety of religious practices and organization of other activities, in such a way raising interest and awareness of Buddhism among the Latvian population.

Religious activity of all Buddhist communities is based on Buddhism teaching or Dharma that unites their members. One of its essential components is religious practice. The communities' religious activities involve a conscious effort to study Buddhism teachings or to participate in the spiritual events of a particular Buddhism tradition. The religious activity, firstly, is constituted by the weekly practices and meditations inside the premises of each community, as well as participation in meditation retreats, book reading and collective study of religious texts.

Since there are no residing Buddhist lamas in Latvia, Buddhist converts, including women, conduct religious activities. Women lead group guided meditation or read meditation texts along with men, and actively participate in discussions and debates on the bases of Buddhism teaching and principles. For example, one of the Drikung Kagyu school followers in Latvia holds the title nDorje Lopö (Master of Vajra) that entitles her to provide Buddhist teachings to all interested individuals. Therefore, sometimes there are organized events in the community she belongs to in which she explains religious texts.

For Buddhist communities and Buddhists in Latvia visits of Buddhist teachers who deliver lectures, explain the main philosophical texts, comment on them and answer the practitioners' questions are of great significance. During these visits, women help with different organizational and preparation works: be it organization of teachings and bringing teachers to Latvia or preparation of meals during the teaching events and cleaning premises after events. Women also are active in promoting Buddhism for more people in Latvia, taking part in the social activities of Buddhist communities that aims to inform society about Buddhism and its existence in Latvia. These are Buddhist teachers' public lectures, information days on Buddhism, receiving Buddhist monks to perform sacral dances and rituals or to create and later destruct sand mandalas, etc.

In addition, some Buddhist female practitioners from Latvia took greater life commitment and become nuns. Two women are ordained in the Drikung Kagye tradition. One nun lives in a Buddhist monastery in Nepal. The other one is Margarita Putnina who took Buddhist nun wows in 2010. Her contribution to the development of Buddhism in Latvia is not only participation in activities within the Buddhist community she belongs to, but also, she is socially active. She writes verses, translates Dalai Lama's books from English into Latvian and she is an active member of the free Tibet movement in Latvia, as well in the Baltic States. In its turn, her daughter, Flera Birmane, not only practices Buddhism. For several years, she studied Buddhism sacral art in Tsering Art School in Katmandu, and her contribution to the development of Buddhism in Latvia is that she is the first female thangha ${ }^{5}$ painter in the Baltic States.

\footnotetext{
5 Thangha - Tibetan Buddhist painting on cotton, silk appliqué, usually depicting a Buddhist deity, scene, or mandala.
} 
The third Buddhist nun, Elga Bridzina Rusina, was born in Latvia but during the World War II her family emigrated to the United States of America. In 2010, Elga Rusina ordinate in Soto Zen Buddhism, but in 2014 she returned to Latvia and founded Soto Zen centre in Riga.

\section{Conclusion}

Since regaining independence, Buddhist groups in Latvia began to form and develop quite rapidly. Similar to the West, where Buddhism characterizes by pluralism and diversity, for more than thirty years all the major Buddhist traditions have found their home in Latvia: Mahayana, represented by the Zen Buddhist groups, Theravada, and three of the four Tibetan Buddhist schools. While in many Asian countries only one particular Buddhist school dominates, in the West there is a tendency for multiple traditions and schools to operate within a single country or even city. This model is also applicable to Latvia, where different schools and traditions coexist in both Riga and Daugavpils [21].

Another important characteristic of modern Buddhism, which is the subject of this article, is 'the active and visible role of women [22]. As Ann Gleig writes in her study "women have played a significant role in both the historical transmission of Buddhism to the West and in shaping a distinctively Western form of Buddhism [23]. Karma Lekshe Tsomo also stresses that in "the past twenty years in all of these Buddhist communities, a trend toward greater visibility, independence, recognition, and equity for women has begun to emerge" [24].

Since establishment of Buddhist groups, organizations, and institutions in the West, many of female Buddhists have received training in Asian models of leadership and adopted these traditional models to lead their organizations. In western countries, women have been establishing Buddhist practice and retreat centres, hospices, and international organizations. Many western Buddhist women are active in social field and are engaged in a range of activities from teaching to translating, charity and social activism, to promoting Buddhism in the West and implementing traditional Buddhist principles and practices in innovative ways in their daily work and activities [25]. Some of these prominent Buddhist women in the West are Rita M. Gross, Judith Simmer-Brown, Pema Chodron, Toni Packer, Robina Courtin.

In this respect, Buddhist women in Latvia do not stay apart from the active and visible role of women in Buddhism in the West and have played a significant role in bringing Buddhism to Latvia and its future development in the country. From the end of 1980s onward, female Buddhists in Latvia are visible in all aspects. They have equal opportunity to engage in the full range of ritual practices, study of Buddhist teaching, and they hold institutional leadership positions in the communities, as well as they are active in the social field.

Since Buddhism in Latvia does not have large history comparing to other Western countries, the future of Buddhist women in Latvia is still being shaped. However, as examples in this article show, women are active in ensuring a quite successful development of Buddhism in Latvia. As fieldwork in Buddhist communities shows that in Latvia in Buddhism women are well educated and more spiritual than men. This fact gives women a strong foundation for learning Buddhism. Thanks to greater mobility opportunities today, as well as to modern technologies, they have access to Buddhism teaching and practices from a diversity of Buddhist temples and practice centres worldwide thus, providing that the future of Buddhism in Latvia will be diverse and will include their active participation and leadership. 


\section{References}

[1] M. Baumann, J. Global Buddhism 2, 1-43 (2001)

[2] A. Wallace, The Spectrum of Buddhist Practice in the West, in Westward Dharma: Buddhism Beyond Asia, 34-50 (Berkeley: University of California Press, 2002)

[3] M. Baumann, Buddhism in Europe: Past, Present, Prospects, in Westward Dharma: Buddhism Beyond Asia, 85-105 (Berkeley: University of California Press, 2002)

[4] M. Baumann,Buddhism in Europe: Past, Present, Prospects, in Westward Dharma: Buddhism Beyond Asia, 85-105 (Berkeley: University of California Press, 2002)

[5] D. Bleiere, I. Butulis, I. Feldmanis. Latvijas vēsture. 20. gadsimts (Rīga: Jumava, 2005)

[6] D. Bleiere, I. Butulis, I. Feldmanis. Latvijas vēsture. 20. gadsimts (Rīga: Jumava, 2005)

[7] Sergey Filatov, Poslesloviye. Religiya v postsovetskoy Rossii [Afterword: Religion in Post-Soviet Russia], in Religiya i obshchestvo: Ocherki religioznoy zhizni sovremennoy Rossii [Religion and Society: Essays on The Religious Life of Contemporary Russia] edited by Sergey Filatov, 470-484 (Moscow, Saint Petersburg: Letniy sad, 2002)

[8] Personal e-mail from Ildeikina, Julia. 22 September 2013

[9] Personal e-mail from Ildeikina, Julia. 22 September 2013

[10] Зарегистрирован “Джигун Кагью Дхарма Чакра Центр,” Буддизм в Poссии Nr. 4 (1992). Pieejams: http://www. buddhismofrussia.ru/buddhismof-russia/br04/, accessed 01.06.2014

[11] Буддизм в России Nr. 4 (1992). Available: http://www.buddhismofrussia. $\mathrm{ru} /$ buddhism-of-russia/br04/

[12] LV_9. Personal interview. 04 April 2009

[13] LV_6. Personal interview. 03 April 2009

[14] "Latvijas Miera Pagodas iesvētī̌ana" (2014). Available at: http://www.sorig. lv/lat/news/34

[15] LV_2. Personal interview. 13 December 2008

[16] LV_ 11. Personal interview. 04 Aprill 2009

[17] LV_ 1. Personal interview. 24 October 2008

[18] J. Trops, "Mūks viesojas Latvijā”, Diena, 12, 2009

[19] T. Šaitere, „Klosterī aiziet nevarēju”, SestDiena, 18, 2001

[20] LV_4. Personal interview. 01 March 2009

[21] D. Keown, C. S. Prebish, Introducing Buddhism, 198 (London: Routledge, 2006)

[22] D. Lopez. A Modern Buddhist Bible, Essential Readings from East and West, (Massachusetts: Beacon Press, 2002)

[23] A. Gleig, Prominent Buddhist Women in the West, in obo in Buddhism, https:// www . oxfordbibliographies . com/view/document/obo-9780195393521/obo9780195393521-0207.xml

[24] K. L. Tsomo, Global Exchange: Women in the Transmission and Transformation of Buddhism, in Trans Buddhism: Transmission, Translation, Transformation, 151-66 (Amherst: University of Massachusetts Press, 2009)

[25] K. L. Tsomo, Women as Leaders in Buddhism. Gender and Women's Leadership: A Reference Handbook (vol. 2), 482-89 (Thousand Oaks, CA: Sage Publications, 2010) 